\title{
Editorial: Novel Isotope Systems and Biogeochemical Cycling During Cryospheric Weathering in Polar Environments
}

\author{
Melissa J. Murphy ${ }^{1}$, Katharine Hendry ${ }^{2 *}$ and Sophie Opfergelt ${ }^{3}$ \\ ${ }^{1}$ Department of Geosciences and Natural Resource Management, Center for Permafrost (CENPERM), University of Copenhagen, \\ Copenhagen, Denmark, ${ }^{2}$ School of Earth Sciences, University of Bristol, Bristol, United Kingdom, ${ }^{3}$ Earth and Life Institute, \\ Environmental Sciences, Université Catholique de Louvain, Louvain-la-Neuve, Belgium
}

Keywords: cryosphere, isotope, permafrost, glacier, geochemistry

Editorial on the Research Topic

Novel Isotope Systems and Biogeochemical Cycling During Cryospheric Weathering in Polar Environments

Cryospheric weathering processes in permafrost and glaciated environments play an essential role in carbon cycling within the Earth system. Chemical weathering of silicate, carbonate and sulfidebearing rocks releases cations and anions that can consume (or release) atmospheric carbon dioxide $\left(\mathrm{CO}_{2}\right)$, as well as biologically important nutrients such as phosphorous, iron and silicon, which can impact downstream ecosystems (Figure 1). How these cryospheric weathering processes will respond to future climate-driven changes in permafrost thaw and glacial melt is difficult to predict due to the role of complex forcing mechanisms and feedbacks.

Isotope geochemistry utilizes changes in the relative abundance of different isotopes due to physical,

Edited and reviewed by: Martyn Tranter,

Aarhus University, Denmark

*Correspondence:

Katharine Hendry

K.Hendry@bristol.ac.uk

Specialty section:

This article was submitted to Geochemistry,

a section of the journal

Frontiers in Earth Science

Received: 29 January 2021 Accepted: 02 February 2021

Published: 11 March 2021

Citation:

Murphy MJ, Hendry K and Opfergelt S (2021) Editorial: Novel Isotope

Systems and Biogeochemical Cycling During Cryospheric Weathering in

Polar Environments.

Front. Earth Sci. 9:660333.

doi: 10.3389/feart.2021.660333 chemical and biological reactions, allowing some of the complexities of cryospheric weathering processes to be unpicked. In recent years, there has been an explosion in the range of stable and radiogenic isotope systems used for the study of high-latitude environments, including isotopes of major elements such as carbon, oxygen, and silicon (e.g., Opfergelt et al., 2013; Kutscher et al., 2017), and trace metal isotopes such as strontium (Hindshaw et al., 2014), lithium (Murphy et al., 2019), iron (Zhang et al., 2015), uranium-series (e.g., Arendt et al., 2018) and rare earth elements (e.g., Clinger et al., 2016). This research topic explores some of the developments in high-latitude field and experimental studies that utilize such geochemical tools to trace the degree and nature of weathering reactions that play a critical role in carbon cycling. The nine contributions to the research topic involve the analysis of traditional $(\mathrm{C}, \mathrm{N}, \mathrm{S}, \mathrm{O})$ and non-traditional $(\mathrm{Mg}, \mathrm{Li}, \mathrm{Si}, \mathrm{Ge})$ isotopes from different samples types such as river waters, lake waters, rocks, sediments, or mineral separates from locations both in the Northern (Greenland, Iceland, Canada, Svalbard) and Southern Hemisphere (Patagonia, Antarctica).

Two papers use isotope geochemistry to explore organic and inorganic carbon cycling within permafrost and active layer soils. Jones et al. show that biogeochemical processes and decomposition pathways of organic carbon in ice-wedge polygons in Svalbard are dependent upon water and organic carbon content. Sulfur $\left(\delta^{34} \mathrm{~S}\right)$ and oxygen $\left(\delta^{18} \mathrm{O}\right)$ isotopes show that iron and sulfate reduction processes dominate in water saturated, high organic carbon environments, whereas sulfide oxidation dominates in drier areas with less organic carbon. Zolkos and Tank use an experimental approach in combination with stable carbon isotopes $\left(\delta^{13} \mathrm{CO}_{2}\right)$ to show that carbonate weathering coupled with sulfide oxidation in recently or previously unthawed Canadian permafrost sediments is a net source of inorganic $\mathrm{CO}_{2}$ to the atmosphere, albeit partly counterbalanced by carbonate buffering. 


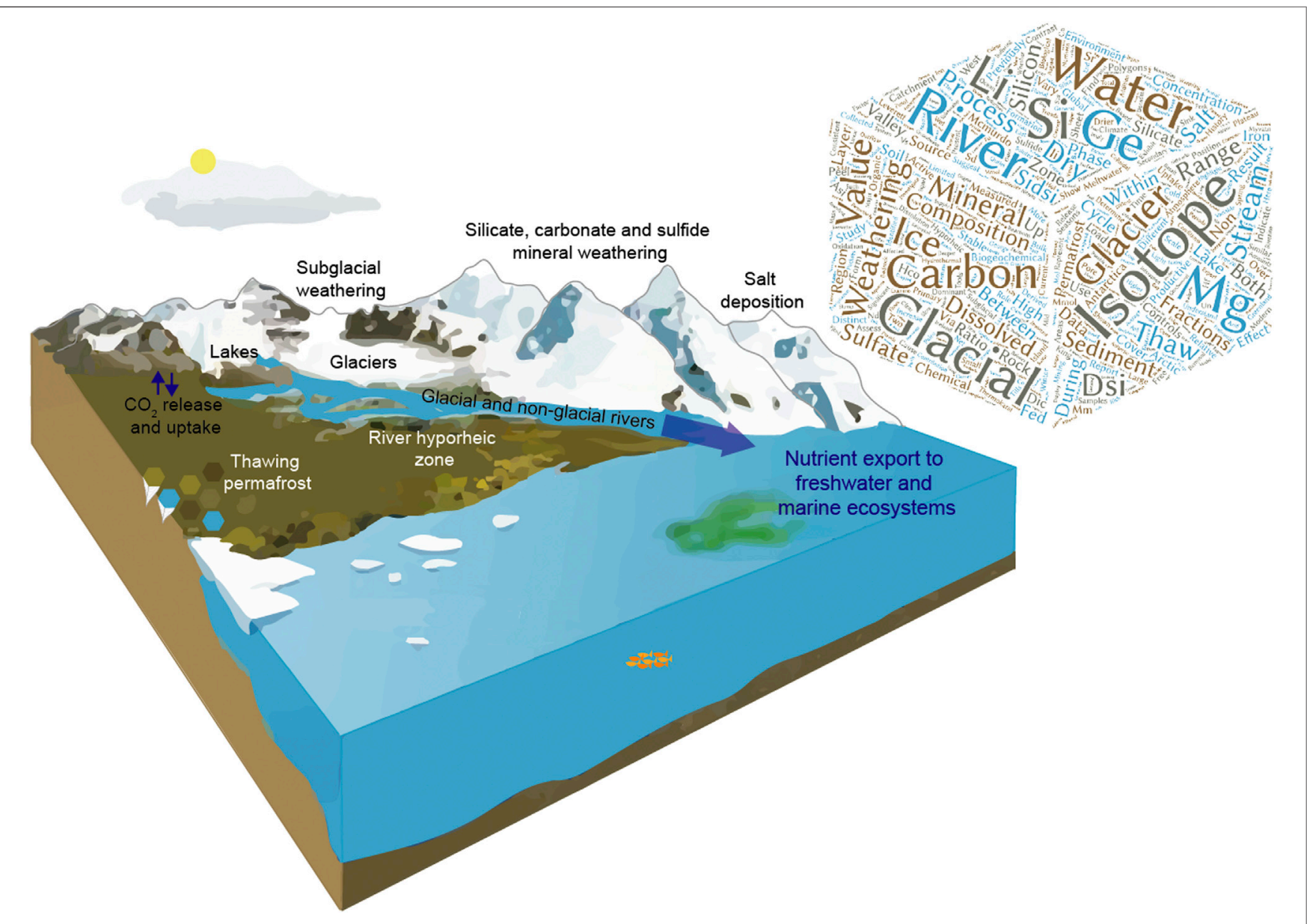

FIGURE 1 | Schematic showing the key cryospheric weathering processes that were investigated in this research topic (Modified from AMAP, 2017). The wordcloud shows the key concepts explored across the contributions, proportionally resized to the number of times word was used throughout titles and abstracts.

Two papers add to the growing body of work combining different isotope systems to understand subglacial weathering processes under the Greenland Ice Sheet. New measurements of magnesium $\left(\delta^{26} \mathrm{Mg}\right)$ and lithium $\left(\delta^{7} \mathrm{Li}\right)$ isotopes by Hindshaw et al. (2014) from the Leverett Glacier catchment, together with a number of radiogenic isotope systems, highlight the importance of the preferential dissolution of silicate and carbonate phases on chemical weathering and carbon cycling in meltwaters. Baronas et al. present new germanium isotope $\left(\Delta^{74} \mathrm{Ge}\right)$ measurements of glacial meltwaters from the Watson River catchment, which together with batch dissolution experiments - reveal that meltwaters are isotopically light and contrasting germanium fractionation mechanisms occur during subglacial dissolutionprecipitation weathering reactions when compared to its "geochemical twin," silicon.

Previous studies have shown that stable silicon isotopes $\left(\delta^{30} \mathrm{Si}\right)$ are isotopically lighter in glacial rivers compared to non-glacial counterparts as a result of subglacial physical crushing and/or precipitation-dissolution reactions involving amorphous silica phases (Hatton et al., 2019). To date, these studies have only focused on Arctic glacial and river systems. Pryer et al. detail the first $\delta^{30} \mathrm{Si}$ measurements across a climate gradient from non-glaciated to glaciated catchments from Chilean Patagonia. Using careful filtration methods, a colloidalsize silica phase comprised predominantly of feldspars was identified in isotopically light, glacial-fed rivers. Not only does this add another mechanism for explaining variation in silica export and isotope mass balance in Arctic glaciated environments, but likely has consequences for other isotope systems.

Glacial meltwaters in the McMurdo Dry Valleys (MDVs) in Antarctica originate from cold-based glaciers in one of the driest places on Earth. Combined $\delta^{30} \mathrm{Si}$ and $\mathrm{Ge} / \mathrm{Si}$ measurements from Crescent Stream in MDVs (Hirst et al.) reflect the formation of amorphous silica phases and secondary clays in an extensive hyporheic zone during freeze-thaw cycles. Interestingly, these data highlight that rivers draining cold-based glaciers have higher $\delta^{30} \mathrm{Si}$ compositions than rivers draining polythermalbased glaciers and similar $\delta^{30} \mathrm{Si}$ compositions to rivers draining permafrost in the Arctic. Hatton et al. present $\delta^{30} \mathrm{Si}$ measurements from Commonwealth Stream in MDVs that show the opposite relationship with dissolved silicon concentrations to that observed 
in rivers draining polythermal glaciers in the Arctic or Antarctic. Such contrasting behavior highlights the different origins of meltwater, with cold-based glaciers characterized by a higher proportion of supraglacial relative to subglacial melt, and dominance of in-stream weathering.

The MDVs are also explored by Diaz et al., who use stable isotopes of carbon, nitrogen and sulfur to investigate the transport of salts from the Central Transantarctic Mountains to the highly saline soils in the MDVs. Their findings show that regional variations in stable isotopes reflect both water availability and different atmospheric inputs of sulfates and nitrates, and evaporation-precipitation of carbonates.

Polar lakes are key sites of further chemical alteration of cryospheric weathering products, biological productivity and nutrient uptake. Pogge von Strandmann et al. present $\delta^{26} \mathrm{Mg}$ records from a groundwater-fed Icelandic lake, fed by both cold and hot springs. Magnesium isotopes are fractionated by changes in lake temperature, as well as a strong seasonal signal due to biogenic calcium carbonate production in summer.

\section{REFERENCES}

AMAP (2017). Snow, water, ice and permafrost in the arctic (SWIPA) 2017. Oslo, Norway: Arctic Monitoring and Assessment Programme (AMAP), 269.

Arendt, C. A., Aciego, S. M., Sims, K. W., Das, S. B., Sheik, C., and Stevenson, E. I. (2018). Influence of glacial meltwater on global seawater $\delta 234$ U. Geochimica Cosmochimica Acta 225, 102-115. doi:10.1016/j.gca.2018.01.007

Bouchard, F., Agnan, Y., Bröder, L., Fouché, J., Hirst, C., Sjöberg, Y., et al. (2020). The SPLASH action group - towards standardized sampling strategies in permafrost science. Adv. Polar Sci. 31 (3). doi:10.13679/j.advps.2020.0009

Clinger, A. E., Aciego, S. M., Stevenson, E. I., Arendt, C. A., and Robbins, M. J. (2016). Implications for post-comminution processes in subglacial suspended sediment using coupled radiogenic strontium and neodymium isotopes. Geomorphology. 259, 134-144. doi:10.1016/j.geomorph.2016.02.006

Hatton, J. E., Hendry, K. R., Hawkings, J. R., Wadham, J. L., Opfergelt, S., Kohler, T. J., et al. (2019). Silicon isotopes in Arctic and sub-Arctic glacial meltwaters: the role of subglacial weathering in the silicon cycle. Proc. R. Soc. A. 475 (2228), 20190098. doi:10.1098/rspa.2019.0098

Hindshaw, R. S., Rickli, J., Leuthold, J., Wadham, J., and Bourdon, B. (2014). Identifying weathering sources and processes in an outlet glacier of the Greenland Ice Sheet using $\mathrm{Ca}$ and $\mathrm{Sr}$ isotope ratios. Geochimica Cosmochimica Acta 145, 50-71. doi:10.1016/j.gca.2014.09.016

Kutscher, L., Mörth, C.-M., Porcelli, D., Hirst, C., Maximov, T. C., Petrov, R. E., et al. (2017). Spatial variation in concentration and sources of organic carbon in the Lena River, Siberia. J. Geophys. Res. Biogeosci. 122, 1999-2016. doi:10.1002/ 2017JG003858
This research topic highlights the important role that isotope geochemistry plays in understanding the mechanistic links between cryospheric processes and climate-weathering feedbacks. Looking to the future, combining multiple isotopic systems with inter-disciplinary approaches will provide insight on the different aspects of the weathering processes occurring under and around ice sheets, and within permafrost. Furthermore, encouraging wider collaborations and standardized field sampling and experimental methodologies (e.g., Bouchard et al., 2020), will allow the geochemical community to better use the large number of existing and complementary datasets from the high-latitude regions to understand cryospheric weathering in polar environments.

\section{AUTHOR CONTRIBUTIONS}

All authors listed have made a substantial, direct, and intellectual contribution to the work and approved it for publication.

Murphy, M. J., Porcelli, D., Pogge von Strandmann, P. A. E., Hirst, C. A., Kutscher, L., Katchinoff, J. A., et al. (2019). Tracing silicate weathering processes in the permafrost-dominated Lena River watershed using lithium isotopes. Geochimica Cosmochimica Acta 245, 154-171. doi:10.1016/j.gca.2018.10.024

Opfergelt, S., Burton, K. W., Pogge von Strandmann, P. A. E., Gislason, S. R., and Halliday, A. N. (2013). Riverine silicon isotope variations in glaciated basaltic terrains: implications for the si delivery to the ocean over glacial-interglacial intervals. Earth Planet. Sci. Lett. 369, 211-219. doi:10.1016/j.epsl.2013.03.025

Zhang, R., John, S. G., Zhang, J., Ren, J., Wu, Y., Zhu, Z., et al. (2015). Transport and reaction of iron and iron stable isotopes in glacial meltwaters on svalbard near kongsfjorden: from rivers to estuary to ocean. Earth Planet. Sci. Lett. 424 201-211. doi:10.1016/j.epsl.2015.05.031

Conflict of Interest: The authors declare that the research was conducted in the absence of any commercial or financial relationships that could be construed as a potential conflict of interest.

The handling editor declared a shared affiliation with one of the authors, $\mathrm{KRH}$ at time of review.

Copyright (c) 2021 Murphy, Hendry and Opfergelt. This is an open-access article distributed under the terms of the Creative Commons Attribution License (CC BY). The use, distribution or reproduction in other forums is permitted, provided the original author(s) and the copyright owner(s) are credited and that the original publication in this journal is cited, in accordance with accepted academic practice. No use, distribution or reproduction is permitted which does not comply with these terms. 